\title{
Non-crop habitats in the landscape enhance spider diversity in wheat fields of a desert agroecosystem
}

\author{
Therese Pluess $^{\mathrm{a}, \mathrm{b}, \mathrm{c}, *}$, Itai Opatovsky ${ }^{\mathrm{b}}$, Efrat Gavish-Regev ${ }^{\mathrm{b}}$, Yael Lubin ${ }^{\mathrm{b}}$, Martin H. Schmidt-Entling ${ }^{\mathrm{c}}$ \\ ${ }^{a}$ University of Fribourg, Ch. du Musée 10, CH-1700 Fribourg, Switzerland \\ ${ }^{\mathrm{b}}$ Mitrani Department of Desert Ecology, Ben-Gurion University of the Negev, 84990 Midreshet Ben-Gurion, Israel \\ ${ }^{\mathrm{C}}$ University of Bern, Baltzerstrasse 6, CH-3012 Bern, Switzerland
}

\begin{abstract}
Spiders (Araneae) are an important group of generalist predators in arable land. In temperate climates, spiders recolonise cropland annually from the surrounding landscape. In arid climates however, irrigated crops and the surrounding landscape matrix offer sharply different habitat conditions and this might negatively affect spider migration into crops. We studied whether the spider fauna in desert crops is influenced by the surrounding landscape in a similar way to that found in temperate climates. Spiders were sampled with pitfall traps in 13 wheat fields (Triticum aestivum L.) in the Negev Desert (Israel). The fields were situated along a gradient from crop- to non-crop-dominated landscapes (1-72\% non-crop habitats). Species richness of spiders in wheat fields increased with the percentage of non-crop habitats in the landscape. In addition, activity-densities of crab spiders (Thomisidae) and cobweb spiders (Theridiidae) were enhanced by high percentages of non-crop habitats in the surrounding landscape. Activity-densities of the dominant sheetweb spiders (Linyphiidae) showed no significant response to landscape composition. As the immigrant spider families employ different foraging strategies than the dominant sheetweb spiders, they functionally enriched the spider fauna in crops and potentially increase the range of prey types consumed by spiders. Thus, non-crop habitats can be expected to increase the potential for biological control by spiders in nearby crops.
\end{abstract}

\section{Introduction}

While the increase in global human population creates a demand for an increase in food production, there is growing consensus that more sustainable agriculture is needed to ensure long-term productivity and stability of ecosystems (Tilman et al., 2002). Many countries in arid or semi-arid regions of the world are challenged with feeding a growing population while environmental conditions are worsening due to human impacts (J. F. Reynolds et al., 2007). Intensification of agriculture in such regions carries the danger of desertification and therefore requires more sustainable production techniques (Tilman et al., 2002; Thomas, 2008). One way to increase sustainability is to make use of naturally occurring ecosystem services, such as the control of agricultural pest species by means of natural enemies rather than by use of chemical pesticides (Riechert, 1999; Loreau et al., 2001; Tilman et al., 2002; Tscharntke et al., 2005a; Farwig et al., 2009).

Generalist predators such as spiders (Araneae) provide an ecosystem service important for sustainable agriculture by feeding on pest insects (Riechert and Lockley, 1984; Symondson et al., 2002).

\footnotetext{
* Corresponding author. Tel.: +4126300 88 67; fax: +41263009698. E-mail address: therese.pluess@unifr.ch (T. Pluess).
}

Spiders display a wide range of foraging methods and as such may reduce herbivore densities (Marc et al., 1999; Schmitz, 2008). Nevertheless, for efficient pest suppression, a large regional species pool is needed (Symondson et al., 2002), so that spiders may quickly colonise cropland after tillage, sowing or harvest. Research on spiders in agroecosystems therefore aims to find ways to preserve and enhance spider activity-density and species richness in arable fields by maintaining a diverse fauna in the agricultural landscape.

Mobile organisms experience their surroundings at a variety of temporal and spatial scales (Tscharntke et al., 2005a). The composition of the landscape around crop fields can influence predator abundance and species richness in crop fields (Prasifka et al., 2004; Schmidt et al., 2005, 2008; Drapela et al., 2008). Conservation of biodiversity in agroecosystems therefore requires a landscape approach (Tilman et al., 2002; Bengtsson et al., 2003; Loreau et al., 2003; Bianchi et al., 2006; Billeter et al., 2008). While landscape effects on arthropod communities in arable fields have been documented for temperate areas (Prasifka et al., 2004; Dauber et al., 2005; Tscharntke et al., 2007; Clough et al., 2007; Drapela et al., 2008; Schmidt-Entling and Döbeli, 2009), we are not aware of similar studies carried out in arid climate zones.

In semi-arid and arid climates such as the Negev desert in Israel, differences between irrigated and fertilised cropland and the arid surroundings are greatly accentuated, and are likely to affect the 
Table 1

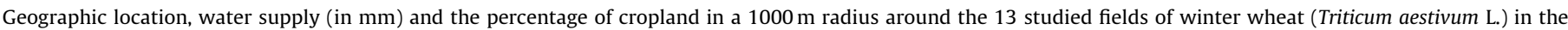
northwest Negev Desert, Israel.

\begin{tabular}{|c|c|c|c|c|c|c|}
\hline Location & $y$-North & $x$-East & Rainfall & Irrigation & Total water & \% Crop \\
\hline Sede Teiman A & $31^{\circ} 18^{\prime} \mathrm{N}$ & $34^{\circ} 42^{\prime} \mathrm{E}$ & 174 & 200 & 374 & 35.5 \\
\hline Sede Teiman B & $31^{\circ} 18^{\prime} \mathrm{N}$ & $34^{\circ} 39^{\prime} \mathrm{E}$ & 159 & 200 & 359 & 98.6 \\
\hline Sede Teiman C & $31^{\circ} 18^{\prime} \mathrm{N}$ & $34^{\circ} 40^{\prime} \mathrm{E}$ & 165 & 200 & 365 & 71.7 \\
\hline Eshel-Hanasi & $31^{\circ} 20^{\prime} \mathrm{N}$ & $34^{\circ} 41^{\prime} \mathrm{E}$ & 186 & 200 & 386 & 50.6 \\
\hline Moshavei HaNegev - Administration & $31^{\circ} 15^{\prime} \mathrm{N}$ & $34^{\circ} 33^{\prime} \mathrm{E}$ & 205 & 180 & 385 & 94.0 \\
\hline Urim & $31^{\circ} 17^{\prime} \mathrm{N}$ & $34^{\circ} 31^{\prime} \mathrm{E}$ & 205 & 80 & 285 & 83.9 \\
\hline Wadi Besor & $31^{\circ} 18^{\prime} \mathrm{N}$ & $34^{\circ} 28^{\prime} \mathrm{E}$ & 194 & 120 & 314 & 55.3 \\
\hline Tal-Or & $31^{\circ} 21^{\prime} \mathrm{N}$ & $34^{\circ} 30^{\prime} \mathrm{E}$ & 284 & 0 & 284 & 97.6 \\
\hline Re'im & $31^{\circ} 22^{\prime} \mathrm{N}$ & $34^{\circ} 29^{\prime} \mathrm{E}$ & 243 & 100 & 343 & 83.4 \\
\hline Be'eri A & $31^{\circ} 24^{\prime} \mathrm{N}$ & $34^{\circ} 30^{\prime} \mathrm{E}$ & 272 & 60 & 332 & 87.8 \\
\hline Be'eri B & $31^{\circ} 23^{\prime} \mathrm{N}$ & $34^{\circ} 30^{\prime} \mathrm{E}$ & 209 & 40 & 249 & 96.0 \\
\hline Be'eri C & $31^{\circ} 26^{\prime} \mathrm{N}$ & $34^{\circ} 30^{\prime} \mathrm{E}$ & 299 & 70 & 369 & 74.5 \\
\hline Be'eri D & $31^{\circ} 26^{\prime} \mathrm{N}$ & $34^{\circ} 29^{\prime} \mathrm{E}$ & 288 & 0 & 288 & 28.6 \\
\hline
\end{tabular}

population dynamics of spiders. Compared with temperate climates, winters are mild and winter rains initiate a period of growth of herbaceous vegetation followed by high herbivore prey abundance in uncultivated land. Hence, in semi-arid climates with winter rainfall, spider activity is reduced during the dry summer months (Cardoso et al., 2007). Spider populations in arable land however are reduced due to the sowing of the winter crop early in November and thus immigration of spiders from the less disturbed surroundings could be important for pest suppression purposes. Gavish-Regev et al. (2008) found that immigrants from non-crop habitats contribute considerably to the spider fauna of wheat fields in the northwest Negev. This suggests that the composition of the landscape around wheat fields can influence within-field densities of spiders also in this climate zone. The present study aims at supplying this knowledge. Given the high mobility of spiders, we expect that the composition of the surrounding landscape would affect local spider communities in wheat fields as follows: Species richness and activity-density of spiders in wheat fields in the northwest Negev are lower than in noncrop habitats during the winter cropping season (Pluess et al., 2008). Thus we predicted that a high percentage of non-crop habitats in the surrounding landscape should increase both species richness and activity-densities of spiders in wheat fields. In contrast to the majority of the other spider families, the crop-dominating Linyphiidae show a strong preference for cropland in the northwest Negev (Gavish-Regev et al., 2008; Pluess et al., 2008), and we therefore expected a lower activity-density of Linyphiidae in landscapes with high percentages of non-crop habitats. Further, arthropods respond to the surrounding landscape at different spatial scales depending on their dispersal abilities (Steffan-Dewenter et al., 2002; Schmidt et al., 2008). Based on this, we analysed activity-densities of abundant spider families at different spatial scales to gain insight into migration distances of these families in the Negev Desert. We tested the following hypotheses:

1. Overall spider species richness and activity-density in wheat fields increase with increasing percentages of non-crop habitats in the surrounding landscape.

2. The different families reach higher activity-densities in landscapes dominated by their preferred habitat, thus reflecting family specific habitat preferences.

3. Cursorial spiders respond to the surrounding landscape at smaller spatial scales than aerial migrants.

\section{Materials and methods}

\subsection{Study sites}

Spiders were sampled in 13 fields of winter wheat (Triticum aestivum L.) in the northwest Negev Desert in Israel. The sampling sites were situated in a region with intensive agriculture northwest of the city of Beer Sheva $\left(31^{\circ} 14^{\prime} \mathrm{N}\right.$, $34^{\circ} 45^{\prime} \mathrm{E}$ ) and were scattered over an area of $30 \mathrm{~km} \times 30 \mathrm{~km}$. This area is dominated by large fields of mostly irrigated annual crops. Two crops are grown within a year. The summer crops typically consist of cotton, sunflowers, melons or peanuts. In the winter months, potatoes and winter wheat are grown. Depending on rainfall and the availability of water, some fields are not irrigated or irrigated only occasionally. The winter wheat of the studied sites was sown in early November, germination and growth were induced by rain or irrigation in late November. Management of the sampled wheat fields varied but no insecticide spraying was applied during the entire sampling season. All but two fields were irrigated. The soils of the fields consisted of loess with varying proportions of sand. The semidesert habitats were composed of loess and sandy soils and were sparsely vegetated with perennial shrubs and geophytes. In some areas, eucalyptus and acacia trees were planted in recent decades. Annual grass and herb species appeared after winter rains. At the first sampling in mid-December, the semi-desert was devoid of green vegetation, while wheat growth had been triggered by local rainfall and/or irrigation. The studied wheat fields were a subset of the 16 fields used in Pluess et al. (2008). Three fields were discarded from the original dataset to achieve better standardisation of local site conditions and wheat growth. The characteristics of the wheat fields included in the current study are listed in Table 1.

\subsection{Spider sampling}

In each wheat field, spiders were sampled with 20 pitfall traps in winter 2006/2007. Pitfall traps were used assuming that numbers of individuals captured per field reflected betweenfield differences in activity-densities for each species (Topping and Sunderland, 1992; Schmidt-Entling and Döbeli, 2009). The traps were $10 \mathrm{~cm}$ deep with an opening diameter of $9 \mathrm{~cm}$ and were situated $50 \mathrm{~m}$ from the border of a winter wheat field. A $50 \%$ dilution of ethylene glycol in water was used as preservative $(150 \mathrm{ml} /$ trap) and a drop of detergent was added to break the solution superficial tension. The traps were opened three times (mid-December, end of January and the second half of February) for 1 week during the growing season of the winter wheat. Captures over the entire trapping period were pooled for the analyses. Upon retrieval, spiders were transferred to $70 \%$ ethanol. All individuals were identified to family and adult individuals to species or morphospecies. Families totalling at least twenty individuals over the entire sampling period were considered frequent enough for separate spatial scale analyses. 

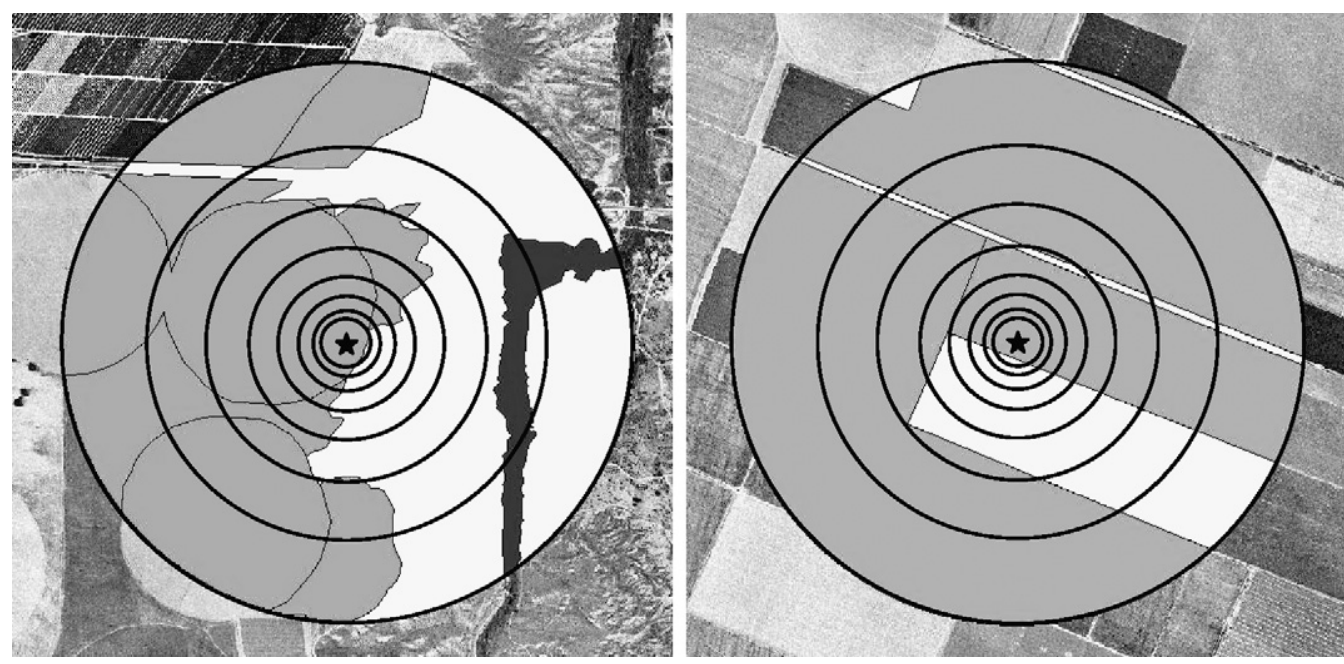

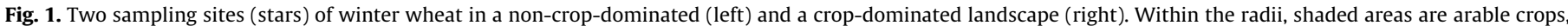

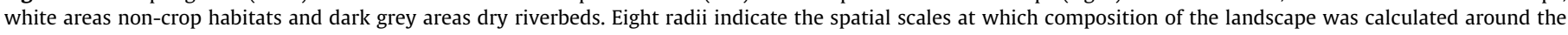
sampling site: $88,125,175,250,350,500,710$ and $1000 \mathrm{~m}$.

\subsection{Landscape analyses}

The studied wheat fields formed a gradient from low to high percentage of non-crop habitats in the surrounding landscape. Landscapes with high and low percentages of non-crop habitats were spatially interspersed over the study area to avoid covariation of landscape composition with climate. Land-use patterns were recorded with the help of aerial photographs and through field inspection within a radius of $1 \mathrm{~km}$ around each study site. Land-use was digitized in vector format with a Geographic Information System (ArcGIS 9.1, ESRI Geoinformatik GmbH, Hannover, Germany). Landscape composition was calculated at eight radii ranging from 88 to $1000 \mathrm{~m}$ around the sampling site, doubling the area under consideration for each subsequent radius (Fig. 1). The different land-use types around the sampling sites were recorded and are shown in Table 2. To assess the influence of landscape composition around the wheat fields, land-use types were divided into crop (the predominant land-use type) and noncrop habitat. Relationships of spider species richness and activitydensity with landscape composition were tested using generalized linear models with quasi-Poisson distribution in $\mathrm{R}$ version 2.6.1 (R Development Core Team, 2007). To compare influences of

\section{Table 2}

Landscape composition around the 13 studied fields of winter wheat in the northwest Negev Desert, Israel. Percentages of major land-use types $1000 \mathrm{~m}$ around sampling sites.

\begin{tabular}{lrcc}
\hline & Mean \pm SE (\%) & Minimum (\%) & Maximum (\%) \\
\hline Crops & & & \\
Annual irrigated crops & $60.3 \pm 8.0$ & 13.7 & 98.6 \\
Annual non-irrigated crops & $10.7 \pm 3.4$ & 0.0 & 40.9 \\
Perennial crops ${ }^{\mathrm{a}}$ & $2.7 \pm 1.3$ & 0.0 & 15.6 \\
Total crops & $73.7 \pm 6.6$ & 28.6 & 98.6 \\
Non-crop habitats & & & \\
Army base & $3.5 \pm 2.7$ & 0.0 & 34.3 \\
Cattle paddock & $0.8 \pm 0.8$ & 0.0 & 10.0 \\
Fallows & $1.1 \pm 1.1$ & 0.0 & 13.8 \\
Planted tree habitats & $3.9 \pm 1.9$ & 0.0 & 23.6 \\
Open water reservoir & $0.4 \pm 0.4$ & 0.0 & 5.8 \\
Semi-desert & & 0.0 & 53.4 \\
Settlements (incl. parks) & $15.2 \pm 5.4$ & 0.0 & 5.0 \\
Total non-crop habitats & $26.3 \pm 6.6$ & 1.3 & 71.4 \\
\hline
\end{tabular}

a Mostly citrus, jojoba.

b Mostly woodlands of eucalyptus trees.

Both natural and semi-natural. the surrounding landscape on activity-densities and species richness across spatial scales, coefficients of determination were plotted against the eight scales at which landscape composition was calculated.

\section{Results}

On average, we caught $116 \pm 9$ (SE) spiders per field, totalling 1512 individuals from 15 families. The catch was dominated by Linyphiidae (sheetweb spiders, 61\%), followed by Lycosidae (wolf spiders, $14 \%$ ), Gnaphosidae (ground spiders, $8 \%$ ), Theridiidae (cobweb spiders, $7 \%$ ), Salticidae (jumping spiders, $2 \%$ ), Corinnidae (corinnid sac spiders, $2 \%$ ) and Thomisidae (crab spiders, 2\%). Families with less than 2\% were: Philodromidae, Zodariidae, Cithaeronidae, Dysderidae, Sparassidae, Clubionidae, Agelenidae, Liocranidae and Zoridae (in order of decreasing activity-density). The 1252 adult spiders belonged to 47 species and morphospecies (listed in Pluess et al., 2008).

Species richness of spiders in wheat fields was significantly enhanced by higher percentages of non-crop habitats in the surrounding landscape (Fig. 2A). This relationship was significant at all scales, with a peak at the $500 \mathrm{~m}$ radius; $t_{1,11}=-5.05, p<0.01$. In contrast to species richness, spider activity-density was not significantly affected by the composition of the surrounding landscape at any of the tested scales (Fig. 2B).

Of the seven most common spider families, two responded significantly to landscape composition. Activity-densities of Thomisidae (Fig. 3A) and Theridiidae (Fig. 3B) were enhanced by high percentages of non-crop habitat in the surrounding landscape. Linyphiidae (Fig. 3C), Lycosidae, Gnaphosidae, Salticidae and Corinnidae were not significantly affected by landscape composition. The response of Thomisidae to landscape composition was similar across all studied spatial scales and strongest at the $1000 \mathrm{~m}$ radius; $t_{1,11}=-2.50, p=0.03$ (Fig. $3 \mathrm{~A}$ ). In contrast, the response of Theridiidae to landscape composition was strongest at a landscape radius of $355 \mathrm{~m}\left(t_{1,11}=-3.89, p<0.01\right)$, and became weaker at the largest scale of $1 \mathrm{~km}$ landscape radius (Fig. 3B).

\section{Discussion}

Non-crop habitats in the agricultural landscapes of the northwest Negev enhanced species richness of spiders in fields of winter wheat. This finding is in agreement with other geographic regions (Öberg et al., 2007; Drapela et al., 2008; 
(A) Species
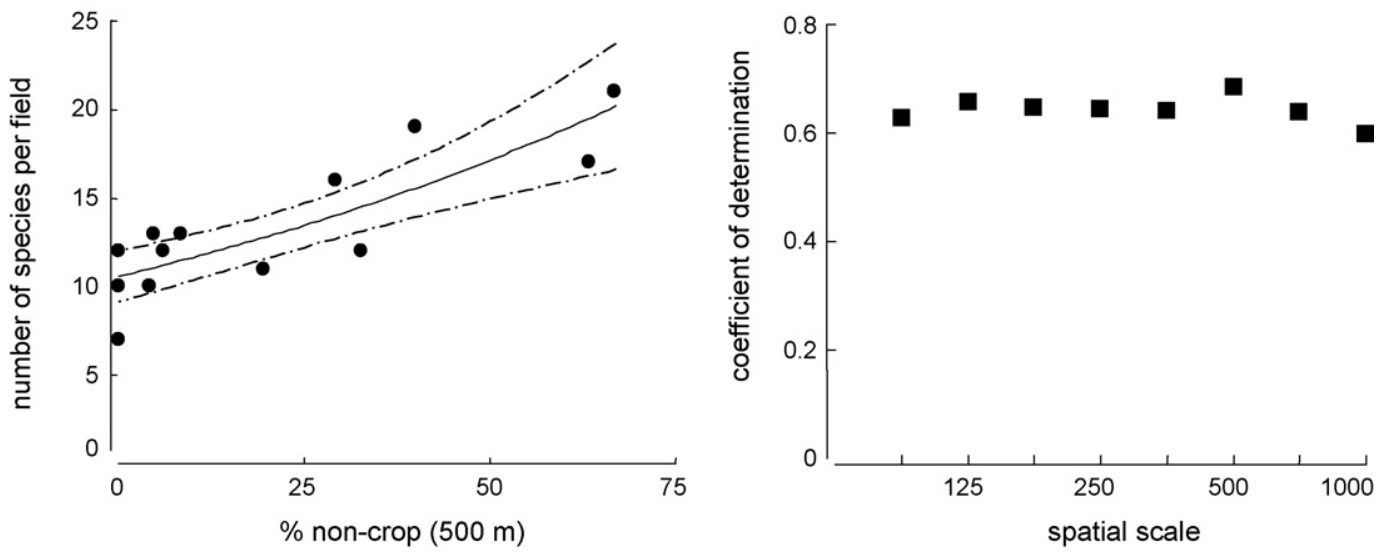

(B) Individuals
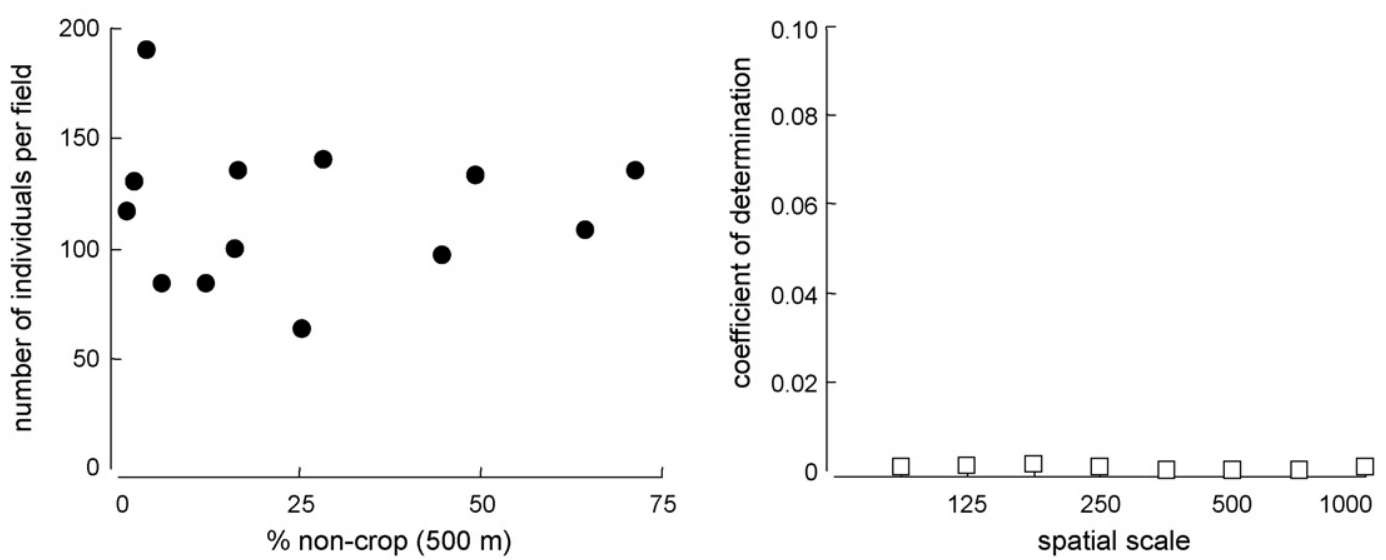

Fig. 2. (A) Species richness and (B) activity-density of spiders in 13 wheat fields in relation to the percentage of non-crop habitats in the landscape (left) and scale dependence of these relationships (right). The solid line is the regression line; the dashed lines denote the $95 \%$ confidence interval. Coefficients of determination are plotted against the spatial scale at which landscape composition was calculated. Filled squares represent significant relationships $(p<0.05)$.

Schmidt et al., 2008; Schmidt-Entling and Döbeli, 2009), and confirms our expectation that a species rich landscape matrix is associated with increased species richness in the sampled wheat fields. Hence, despite being adapted to arid habitat conditions, some native species migrated into the crops, considerably adding to the local diversity, during the sampled period of winter and early spring. Remarkably, spiders in natural semidesert of the same study region were unaffected by landscape composition (Opatovsky et al., 2010). Thus, spiders in crop fields responded to the amount of non-crop habitats in the surrounding landscape, but not vice versa. Crop fields could reduce spiders in semi-desert by drawing individuals from local populations, thus representing a sink habitat (Tscharntke et al., 2005b, 2007; Rand et al., 2006). Alternatively, crop fields could enhance spider assemblages in semi-desert through spillover of individuals that benefit from the high productivity of crop fields (Tscharntke et al., 2005b, 2007; Rand et al., 2006). The lack of an influence of crop fields on spiders in semi-desert may be due to the hostile, arid character of the semi-desert for agrobiont species. In addition, the high stability of semi-desert allows persistence of drought-adapted spider species over long time periods, which could make them resistant against immigration. In contrast, crop fields are subject to several major disturbance events per year, which makes them dependant on frequent recolonisation from the surrounding landscape (Wissinger, 1997; Öberg et al., 2008).
The different spider families were not always affected by landscape composition as predicted. For instance, the lack of response to landscape composition by the dominant Linyphiidae was unexpected. In Europe, Linyphiidae benefit from a high percentage of non-crop habitats in the landscape, which serve as their winter refuge (Schmidt and Tscharntke, 2005; SchmidtEntling and Döbeli, 2009). In contrast to these findings, Linyphiidae in the northwest Negev clearly preferred cropland over natural semi-desert (Pluess et al., 2008; Gavish-Regev et al., 2008). Nonetheless, they did not benefit from higher percentages of crops in the landscape matrix investigated here. More research is needed to determine if Linyphiidae colonise arable fields in the Negev over much larger distances than examined in the current study, or if they persist locally (Gavish-Regev et al., 2008). The positive response of Thomisidae to high percentages of non-crop habitats was in accordance with their preference of semi-desert over arable fields (Pluess et al., 2008). In contrast, the positive response of Theridiidae to high percentages of non-crop habitat is not supported by a corresponding habitat preference. Theridiidae showed no significant preference for either arable fields or semidesert (Pluess et al., 2008). However, at least one species colonises wheat fields from non-crop habitats in the surrounding landscape (Gavish-Regev et al., 2008), and this might account for the positive response to semi-desert in the landscape.

The different spider families were expected to respond to landscape composition at scales that reflect their migration modes. 
(A) Thomisidae
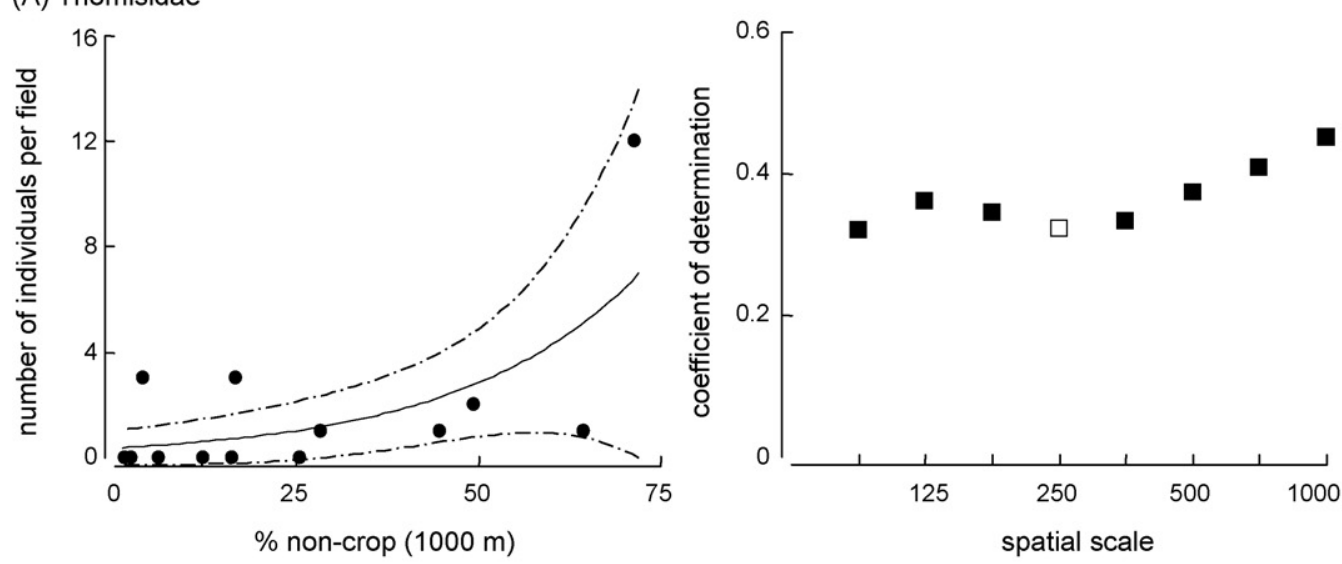

(B) Theridiidae
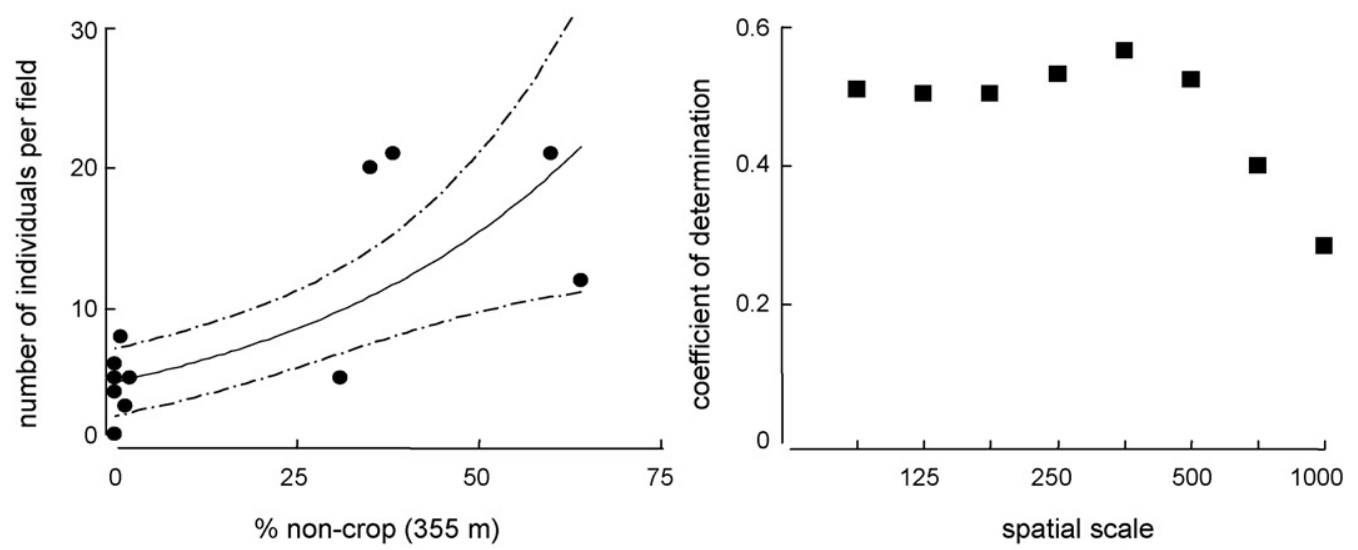

(C) Linyphiidae
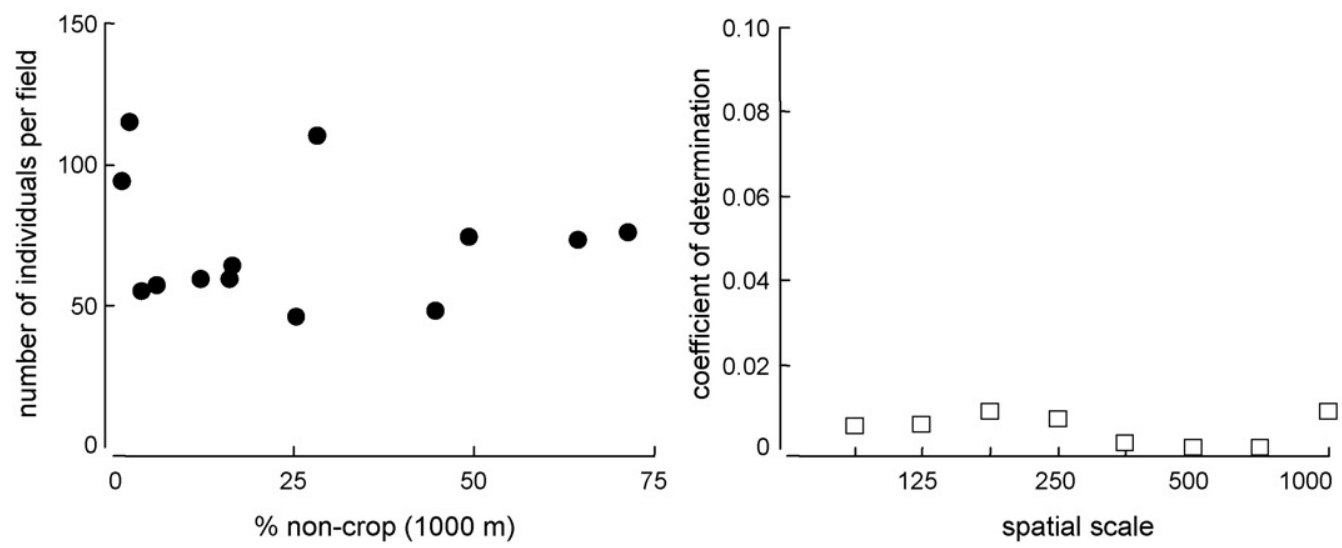

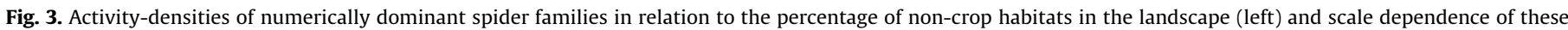

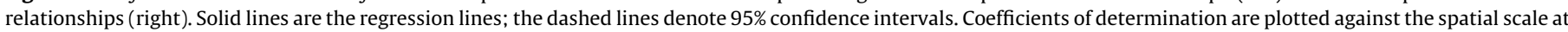

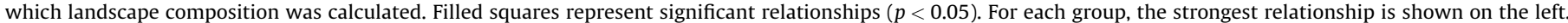

Thus we expected that predominantly cursorial families would respond to the landscape composition at the smaller scales investigated here. However, our expectations were not met: The dominant cursorial families in our dataset, Lycosidae and Gnaphosidae, were not affected by landscape composition at any of the tested scales, suggesting that they do not depend on non-crop habitat at the landscape level to recolonise arable land in our study system. This may at least be true for Lycosidae, which occur in similar activity-densities in crops and semi-desert, while Gnaphosidae clearly prefer semi-desert to arable land (Pluess et al., 2008). Thus, Gnaphosidae should depend on semi-desert for recolonisation (see also Gavish-Regev et al., 2008), but what affects their migration patterns will need further investigation. Significant effects of the surrounding landscapes at the largest scales were found for the cursorial Thomisidae (Gavish-Regev et al., 2008). While nothing is known about ballooning activities of spiders in the Negev, it is known for Europe that, depending on species, Thomisidae can have high frequencies of aerial dispersal (Bonte et al., 2003). Thus, for example, the response of the thomisid Xysticus cristatus (Clerck, 1757) to landscape composition in temperate Europe was strongest at the largest studied scale of $3 \mathrm{~km}$ radius (Schmidt et al., 2008). Thus, the immigration of 
Thomisidae into fields may be aided by ballooning, despite their good walking abilities. Families such as Linyphiidae and Theridiidae are known for high frequencies of airborne dispersal in temperate climate zones (Marc et al., 1999; Bell et al., 2005) and Linyphiidae in Europe are affected by landscape composition at large spatial scales (Schmidt et al., 2008). In our study system, no landscape effect was found for Linyphiidae, and Theridiidae responded most strongly at small to medium scales, suggesting that aerial dispersal in these families is less common in the Negev Desert. Nevertheless, in the study by Gavish-Regev et al. (2008), theridiid colonisation of a wheat field was consistent with dispersal by ballooning. This highlights the need for studies of spider ballooning in semi-desert regions (Bell et al., 2005). Meteorological conditions and/or ecological reasons may impede high aerial dispersal rates in semi-desert (Bell et al., 2005; A. M. Reynolds et al., 2007). In temperate climates, ballooning behaviour varies greatly between species (Bonte et al., 2003), but it is most frequent in Linyphiidae, probably because ballooning Linyphiidae are likely to land in suitable (humid) habitats. In arid climate zones however, natural habitats of most Linyphiidae are the rare wetlands that provide sufficient moisture. Because airborne spiders have little control over direction and duration of their flight, it is unlikely that ballooning spiders can re-locate themselves to a rare habitat type. Thus, evolution may select against ballooning behaviour of moisture-dependent spiders in arid environments. This could explain the possibly more sedentary lifestyle of Linyphiidae in crops in Israel (Gavish-Regev et al., 2008), and the absence of landscape effects on Linyphiidae in our study. Alternatively, Linyphiidae could balloon over even larger distances in semi-desert compared to Europe, and consequently respond to landscape composition at larger scales than those investigated in the current study (Gavish-Regev et al., 2008).

The insurance hypothesis states that in a changing and frequently disturbed environment such as arable land, stability and resilience of ecosystem services depend on high levels of biodiversity (Bengtsson et al., 2003; Tscharntke et al., 2005a; Tylianakis et al., 2006). Some studies have shown that high spider diversity is desirable for pest suppression (Riechert and Lawrence, 1997), since a diverse predator fauna covers more hunting strategies and feeds on a wider range of prey types (Marc and Canard, 1997; Sunderland, 1999). The spider community in the Negev wheat fields was strongly dominated by Linyphiidae, and even though this is a species rich taxon, sheetwebs are the predominant foraging strategy in this habitat type (Gavish-Regev et al., 2009). The observed increase of freely hunting Thomisidae with non-crop habitats in the landscape may favour natural pest control, since cursorial spiders can retard initial population growth of cereal aphids (Birkhofer et al., 2008). Thus, Thomisidae may supplement the activity of Linyphiidae in feeding on aphids and have the potential to reduce aphid populations (Harwood et al., 2004). In contrast, cursorial spiders may reduce pest suppression through interference with web-building species (Nyffeler and Sunderland, 2003; Denno et al., 2004). As a consequence, freely hunting wolf spiders can suppress or enhance herbivore densities, depending on the situation (Schmidt-Entling and Siegenthaler, 2009). Thus, more research is needed to reveal the consequences of variation in landscape composition on pest suppression in agroecosystems.

\section{Acknowledgements}

We would like to thank all the farmers who allowed us to access their fields. Special thanks go to Iris Museli, Gershom Levy and Milan Rezac for assistance in spider identification and Heather Murray, Yann Clough and Jason Tylianakis for useful comments on earlier versions of the manuscript and for linguistic advice and to
Florian Menzel and Fränzi Korner for statistical advice. Four anonymous reviewers provided valuable comments on an earlier version of this manuscript. This study was supported by the Bern University Research Foundation. This is publication number 666 of the Mitrani Department of Desert Ecology.

\section{References}

Bell, J.R., Bohan, D.A., Shaw, E.M., Weyman, G.S., 2005. Ballooning dispersal using silk: world fauna, phylogenies, genetics and models. Bull. Ent. Res. 95, 69-114.

Bengtsson, J., Angelstam, P., Elmqvist, T., Emanuelsson, U., Folke, C., Ihse, M. Moberg, F., Nyström, M., 2003. Reserves, resilience and dynamic landscapes. Ambio 32, 389-396

Bianchi, F.J.J.A., Booji, C.J.H., Tscharntke, T., 2006. Sustainable pest regulation in agricultural landscapes: a review on landscape composition, biodiversity and natural pest control. Proc. R. Soc. Lond. B 273, 1715-1727.

Billeter, R., Liira, J., Bailey, D., Bugter, R., Arens, P., Augenstein, I., Aviron, S., Baudry, J., Bukacek, R., Burel, F., Cerny, M., De Blust, G., De Cock, R., Diekötter, T., Dietz, H., Dirksen, J., Dormann, C., Durka, W., Frenzel, M., Hamersky, R., Hendrickx, F., Herzog, F., Klotz, S., Koolstra, B., Lausch, A., Le Coeur, D., Maelfait, J.P., Opdam, P., Roubalova, M., Schermann, A., Schermann, N., Schmid, T., Schweiger, O., Smulders, M.J.M., Speelmans, M., Simova, P., Verboom, J., van Wingerden, W.K.R.E., Zobel, M., 2008. Indicators for biodiversity in agricultural landscapes: a pan-European study. J. Appl. Ecol. 45, 141-150.

Birkhofer, K., Gavish-Regev, E., Endlweber, K., Lubin, Y.D., von Berg, K., Wise, D.H., Scheu, S., 2008. Cursorial spiders retard initial aphid population growth at low densities in winter wheat. Bull. Ent. Res. 98, 249-255.

Bonte, D., Vandenbroecke, N., Lens, L., Maelfait, J.P., 2003. Low propensity for aerial dispersal in specialist spiders from fragmented landscapes. Proc. R. Soc. Lond. B 270, 1601-1607.

Cardoso, P., Silva, I., De Oliveira, N.G., Serrano, A.R.M., 2007. Seasonality of spiders (Araneae). in Mediterranean ecosystems and its implications in the optimum sampling period. Ecol. Entomol. 32, 516-526.

Clough, Y., Kruess, A., Tscharntke, T., 2007. Local and landscape factors in differently managed arable fields affect the insect herbivore community of a non-crop plant species. J. Appl. Ecol. 44, 22-28.

Dauber, J., Purtauf, T., Allspach, A., Frisch, J., Voigtländer, K., Wolters, V., 2005. Local vs. landscape controls on diversity: a test using surface-dwelling soil macroinvertebrates of differing mobility. Global Ecol. Biogeogr. 14, 213-221.

Denno, R.F., Mitter, M.S., Langellotto, G.A., Gratton, C., Finke, D.L., 2004. Interactions between a hunting spider and a web-builder: consequences of intraguild predation and cannibalism for prey suppression. Ecol. Entomol. 29, 566-577.

Drapela, T., Moser, D., Zaller, J.G., Frank, T., 2008. Spider assemblages in winter oilseed rape affected by landscape and site factors. Ecography 31, 254-262.

Farwig, N., Bailey, D., Bochud, E., Herrmann, J., Kindler, E., Reusser, N., Schuepp, C. Schmidt-Entling, M.H., 2009. Isolation from forest reduces pollination, seed predation and insect scavenging in Swiss farmland. Landscape Ecol. 24, 919927.

Gavish-Regev, E., Lubin, Y., Coll, M., 2008. Migration patterns and functional groups of spiders in a desert agroecosystem. Ecol. Entomol. 33, 202-212.

Gavish-Regev, E., Rotkopf, R., Lubin, Y., Coll, M., 2009. Consumption of aphids by spiders and the effect of additional prey: evidence from microcosm experiments. BioControl 54, 341-350.

Harwood, J.D., Sunderland, K.D., Symondson, W.O.C., 2004. Prey selection by linyphiid spiders: molecular tracking of the effects of alternative prey on rates of aphid consumption in the field. Mol. Ecol. 13, 3549-3560.

Loreau, M., Naeem, S., Inchausti, P., Bengtsson, J., Grime, J.P., Hector, A., Hooper, D.U., Huston, M.A., Rarffaelli, D., Schmid, B., Tilman, D., Wardle, D.A., 2001. Biodiversity and ecosystem functioning: current knowledge and future challenges. Science 294, 804-808.

Loreau, M., Mouquet, N., Gonzalez, A., 2003. Biodiversity as spatial insurance in heterogeneous landscapes. Proc. Natl. Acad. Sci. U.S.A. 22, 12765-12770.

Marc, P., Canard, A., 1997. Maintaining spider biodiversity in agroecosystems as a tool in pest control. Agric. Ecosyst. Environ. 62, 229-235.

Marc, P., Canard, A., Ysnel, F., 1999. Spiders (Araneae) useful for pest limitation and bioindication. Agric. Ecosyst. Environ. 74, 229-273.

Nyffeler, M., Sunderland, K.D., 2003. Composition, abundance and pest control potential of spider communities in agroecosystems: a comparison of European and US studies. Agric. Ecosyst. Environ. 95, 579-612.

Öberg, S., Ekbom, B., Bommarco, R., 2007. Influence of habitat type and surrounding landscape on spider diversity in Swedish agroecosystems. Agric. Ecosyst. Environ. 122, 211-219.

Öberg, S., Mayr, S., Dauber, J., 2008. Landscape effects on recolonisation patterns of spiders in arable fields. Agric. Ecosyst. Environ. 123, 211-218.

Opatovsky, I., Pluess, T., Schmidt-Entling, M.H., Gavish-Regev, E., Lubin, Y., 2010. Are spider assemblages in fragmented, semi-desert habitat affected by increasing cover of agricultural crops? Agric. Ecosyst. Environ. 135, 233-237.

Pluess, T., Opatovsky, I., Gavish-Regev, E., Lubin, Y., Schmidt, M.H., 2008. Species richness and densities of spiders in wheat fields and semi-desert in the Negev (Israel). J. Arachnol. 36, 368-373.

Prasifka, J.R., Heinz, K.M., Minzenmayer, R.R., 2004. Relationships of landscape, prey and agronomic variables to the abundance of generalist predators in cotton (Gossypium hirsutum) fields. Landscape Ecol. 19, 709-717. 
R Development Core Team, 2007. R: A Language and Environment for Statistical Computing. R Foundation for Statistical Computing, Vienna, Austria. , http:// www.R-project.org.

Rand, T.A., Tylianakis, J.M., Tscharntke, T., 2006. Spillover edge effects: the dispersal of agriculturally subsidized insect natural enemies into adjacent natural habitats. Ecol. Lett. 9, 603-614.

Reynolds, A.M., Bohan, D.A., Bell, J.R., 2007. Ballooning dispersal in arthropod taxa: conditions at take-off. Biol. Lett. 3, 237-240.

Reynolds, J.F., Stafford Smith, D.M., Lambin, E.F., Turner, B.L., Mortimore, M., Batterbury, S.P.J., Downing, T.E., Dowlatabadi, H., Fernandez, R.J., Herrick, J.E., HuberSannwald, E., Jiang, H., Leemans, R., Lynam, T., Maestre, F.T., Ayarza, M., Walker, B., 2007. Global desertification: building a science for dryland development Science 316, 847-851.

Riechert, S.E., 1999. The hows and whys of successful pest suppression by spiders: insights from case studies. J. Arachnol. 27, 387-396.

Riechert, S.E., Lockley, T., 1984. Spiders as biological control agents. Annu. Rev. Entomol. 29, 199-320.

Riechert, S.E., Lawrence, K., 1997. Test for predation effects of single versus multiple species of generalist predators: spiders and their insect prey. Ent. Exp. Appl. 84, 147-155.

Schmidt, M.H., Tscharntke, T., 2005. Landscape context of sheetweb spider (Araneae: Linyphiidae) abundance in ceral fields. J. Biogeogr. 32, 467-473.

Schmidt-Entling, M.H., Döbeli, J., 2009. Sown wildflower areas to enhance spiders in arable fields. Agric. Ecosyst. Environ. 133, 19-22.

Schmidt-Entling, M.H., Siegenthaler, E., 2009. Herbivore release through cascading risk effects. Biol. Lett. 5, 773-776.

Schmidt, M.H., Roschewitz, I., Thies, C., Tscharntke, T., 2005. Differential effects of landscape and management on diversity and density of ground-dwelling farmland spiders. J. Appl. Ecol. 42, 281-287.

Schmidt, M.H., Thies, C., Nentwig, W., Tscharntke, T., 2008. Contrasting responses of arable spiders to the landscape matrix at different spatial scales. J. Biogeogr. 35, 157-166.
Schmitz, O.J., 2008. Effects of predator hunting mode on grassland ecosystem function. Science 319, 952-954.

Steffan-Dewenter, I., Münzenberg, U., Bürger, C., Thies, C., Tscharnktke, T., 2002. Scale-dependant effects of landscape context on three pollinator guilds. Ecology 83, 1421-1432.

Sunderland, K., 1999. Mechanisms underlying the effects of spiders on pest populations. J. Arachnol. 27, 308-316.

Symondson, W.O.C., Sunderland, K.D., Greenstone, M.H., 2002. Can generalist predators be effective biocontrol agents? Annu. Rev. Entomol. 47, 561-594.

Thomas, R.J., 2008. 10th Anniversary Review: addressing land degradation and climate change in dryland agroecosystems through sustainable land management. J. Environ. Monitor. 10, 595-603.

Tilman, D., Cassman, K.G., Matson, P.A., Naylor, R., Polasky, S., 2002. Agricultural sustainability and intensive production practices. Nature 418, 671-677.

Topping, T., Sunderland, K.D., 1992. Limitations in the use of pitfall traps in ecological studies exemplified by a study of spiders in a field of winter wheat. J. Appl. Ecol. 29, 485-491.

Tscharntke, T., Klein, A.M., Kruess, A., Steffan-Dewenter, I., Thies, C., 2005a. Landscape perspectives on agricultural intensification and biodiversity - ecosystem service management. Ecol. Lett. 8, 857-874.

Tscharntke, T., Rand, T.A., Bianchi, F.J.J.A., 2005b. The landscape context of trophic interactions: insect spillover across the crop-noncrop interface. Ann. Zool. Fenn. 42, 421-432.

Tscharntke, T., Bommarco, R., Clough, Y., Crist, T.O., Kleijn, D., Rand, T.A., Tylianakis, J.M., van Nouhuys, S., Vidal, S., 2007. Conservation biological control and enemy diversity on a landscape scale. Biol. Control 43, 294-309.

Tylianakis, J.M., Tscharntke, T., Klein, A.M., 2006. Diversity, ecosystem function, and stability of parasitoid host interactions across a tropical habitat gradient. Ecology 87, 3047-3057.

Wissinger, S.A., 1997. Cyclic colonization in predictably ephemeral habitats: a template for biological control in annual crop systems. Biol. Control 10, 415. 